\title{
The Role of Sustainable Accounting on the Uphold of Sustainable Development at the Jordanian Industrial Sector
}

\author{
Omar Ikbal Tawfic ${ }^{1}$, Tariq H. Dorgham ${ }^{1} \&$ Mohammad Rababah ${ }^{2}$ \\ ${ }^{1}$ Faculty of Economics and Administrative Sciences, Applied Science University, Jordan \\ ${ }^{2}$ Faculty of Economics and Administrative Sciences, Jerash University, Jordan \\ Correspondence: Tariq H. Dorgham, Department of accounting, Faculty of Economics and Administrative, \\ Applied Science University, Amman, Jordan. E-mail: t.hanidorgham@yahoo.com
}

Received: September 11, 2014

doi:10.5539/ijef.v6n12p135
Accepted: October 27, 2014 Online Published: November 25, 2014

URL: http://dx.doi.org/10.5539/ijef.v6n12p135

\begin{abstract}
This paper aims to explore the role of sustainable accounting on the uphold of sustainable development at the Jordanian Industrial sector. To approach to this ending, 20 companies were randomized to form the study sample, and a questionnaire was developed and distributed among the sampling unit that consisted of 150 individuals. out of the whole distributed, 135 were returned, and only 120 were statistically valid, therefore, they were subjected to the statistical analysis using the statistical package of social science (SPSS). The researchers adopted the descriptive analytical approach to analyze the gathered data, several results were approached among of which:

1) There is a positive statistical significant correlation between the sustainable accounting and the uphold of sustainable development at the Jordanian Industrial sector. the study revealed that there is a consensus among the respondents in regard to the applicability of sustainable development since it allows development to meet needs and desires of the present and future generations nevertheless the relevant legislations are not enough to empower the environmental preservations.

2) There is a positive statistically significant correlation at $(\alpha=0.05)$ between the environmental financial accounting and the uphold of sustainable development at the Jordanian industrial sector, the study analysis indicated that there are a poor amount of environmental information disclosed in the financial statements; even though the policies and procedures in which the environmental officials and accountants are empowered with is taking a growing trend to promote for the sustainable development.

3) There is a positive statistical significant correlation at $(\alpha=0.05)$ between the environmental management accounting and the uphold of sustainable development at the Jordanian industrial sector. The study analysis revealed that the Jordanian Industrial sector is surrounding the environmental aspects with a minor interest if compared with the social and economical aspects due to the fact that the environmental response by the firms are limited to the legislations enacted by the governmental bodies to avoid any foreseeable penalties.
\end{abstract}

Keywords: environmental management accounting, financial management accounting, sustainable accounting, sustainable development

\section{Introduction}

The sustainable development can be viewed as an organizing principle to the human life, since it aims to limit the available resources utilization to the growing needs of the human factor, thus preserving the chance of utilizing those resources by the upcoming future generation (Free encyclopedia, Wikipedia, Online). to realize this goal, the environmental issues should be integrated with the entities in way that oblige them to consider the environmental issues on the accounting, and legal, and financial, and technical level (Nicolae et al., 2010, p. 209).

Accordingly it can be said that if we want to see such integration coming through, the funds dedicated for production should be controlled by the governing bodies of the sector, such control can be realized by enacting an environmental laws that has a costly consequences based on the production level, those companies who cannot afford the increase in production funds will tend to reduce its usual production thus decreasing the natural resources consumption. due to the cost of implementing the environmental laws, the accounting department tends to quantify those transactions and disclose them separately within the financial statement. 
The question that arises at the moment which department is more capable of handling the environmental information? Jeliazkov Dimităr, in a study of his called" Accounting can and should be involved in environmental protection", concluded that the only subdivision that could meet this challenge, is the accounting department (Jeliazkov, 2009, p. 52). Accordingly this article aims to test the role of sustainable accounting (Financial, Cost, Managerial) on the sustainable development.

\section{Material Studied, Area Descriptions}

\subsection{Sustainable Development}

The first emergence of the sustainable development was during a conference organized by the united nation in Stockholm in 1972 to discuss the human environment, the said conference was considered a major global step towards the interest in environment, due to the discussed topics geared to cover the environmental issues and their relationship with poverty and the absences of development that was announced to be the greatest enemies of environment (Al-Rayashi, None).

The reaped results of the above mentioned conference embodied in the establishment of the united nation environment program, that emphasized on the need to follow the environmental programs to enhance the environmental corporation between different countries (Sheikh, 2002). The concept of sustainable development occupied the forefront of Rio loud Janeiro conference held in Brazil in 1992, where it was publicly acknowledged that the quality of the environment and the safety of the economy are linked together, accordingly the global environmental cooperation between the underdeveloped and developed countries in terms of common interests to protect the future of the earth (Albu et al., 2011).

The World Commission on Environment and Development has defined Sustainable development as "The development that Allows to meet the needs and requirements of the present generation without compromising the ability of future generations to meet their own needs". World Commission on Environment and Development (1987) (OECD, 2002).

Meanwhile, The Rio Conference defined the Sustainable Development as "the right to fulfill development so as to achieve an equal balance between the developmental and environmental needs of present and future generations "(Report of the United Nations, 1992).

On the other hand, Brundtland's report was tailored to emphasis on the need to prepare for three main elements of the sustainable development (Economical growth, Environmental quality, social equity) (Kee \& Haan, 2009). Therefore, it can be said that the environmental issues should be dealt with in a comprehensive manner that calls for the integration of economical and social needs without undermining the natural resource systems to guarantee the continuity of luxuries living conditions of the human factor .

\subsection{Environment Accounting}

The environment can be viewed as the main source that provides the whole economic sectors with the production elements required for their continuity, simultaneously, avoiding the natural resource degradation is crucial to ensure the economic and human well-being, with such contradiction in mind, a sensitization of balance becomes a must to rationalize the natural resources consumption, especially in light of the increasing environmental problems such as glacier Meltdown, deforestation, Global warming, rapid changes in climate, and pollution of all kinds such as water, air. (Qureshi, et al., p. 93) Indicated that the awareness about the environmental safety is essential to achieve the ecological balance, as such knowledge might set forth the companies to draft an environmental policy; take steps to control pollution; comply with the related rules and regulations; and even might set aside part of its funds to protect the environment, which in turn will lead to account for the use of substances that might harm the environment.

Accordingly, it can be concluded that the awareness of the economic sectors in regard to the environmental issues should be accompanied with the public awareness about the same topic; to assure the required influence needed when enacting the environmental rules and regulations, as such integration will help to understand the importance of such rules to the human well-being, accordingly changing the course of actions conducted by the society members towards the required ending. The knowledge acquired during the schooling phases and shaped up during the adulthood is considered indispensible condition to the development of the pro-ecological lifestyle, on the other hand, environmental public awareness is affected by the factors governing the behavior of the society member (cultural, religious, family connections and organization, professional and social life), such know-how will help to establish the foundation of the relevant environmental programs oriented at the public decision making process to resolve an environmental problems(UNEP, 2014, Online).

Public awareness is taking a growing trends, however, there still much to be done specially in the 
underdeveloped countries, several key ways has been identified by the united nations environmental program such as the targeted efforts, local outreach, the media, and education to promote for the environmental awareness (Quick, 2014, online). The increased awareness among the various sectors of a community plays a genuine role in achieving what so called the sustainable development, since the individual, economical, governmental decisions will tend to incorporate the components of sustainable development and that is the Social, Economical, and Environmental dimensions. Therefore, it can be said that equilibrium between the three component is a must to sustain a balance between the economical growth, national income and the usage of the environmental resources, thus realizing an acceptable social differences, accordingly, not jeopardize the future needs. In this sense sustainable development is defined as the "Development that meets the needs of the present without compromising the ability of future generations to meet their own needs" (Strange \& bayley, 2008, p. 24).

The environmental awareness is increasingly spreading as a consequence to the tight growing of the environmental legislations; such stream have led to the favorable birth of the need to adjust the accounting standards to provide bases on which to record; compare and analyze the financial position of an enterprise; thus judging it's all in all performance, even though some standards have a particular relevance to the environmental issues; for example IAS 37 Provisions, Contingent Liabilities, Contingent Assets (i.e taking provisions for the clean-up costs and penalties for unlawful damages) (Moisescu \& Mihai, 2006, p. 80).

To obtain a strong sustainable development, the natural resources should be viewed as a complementary capital to that of the manufactured one, In other words, the renewable resources should be depleted at the level of their growth, meanwhile the non renewable resources should be depleted at the rate for which the renewable substitute are available (Lange, 2003, p. 3). In this sense it can be said that a quantified data base that identifies the resources in terms of their type, depletion level for renewable resources, the substitute availability for non renewable resources, quantity, quality, the type of resources required by each industry; is required to shape up the potential decision in a way that will incentivize the rationality of the natural resources utilization; thus enhancing the entity's role as a social responsible member that seeks the all in all economic and human well-being.

Following the upper said stream requires a close look at what so called the Ecosystem and the associated services or ecosystem services which can be defined as "the process through which benefits can be rendered to humans" (Koellner, 2011, p. 13). In this sense ecosystem services denotes the benefits of nature to households, communities, and economies. meanwhile the business ecosystem is defined as "the dynamic structure which consists of interconnected population of organizations such as large or small firms, Universities, training centers, Suppliers, and other parties" (Feher, 2006, p. 295). a combination between the ecosystem services and the business ecosystem of an enterprise should help to identify and quantify the resources required by the entity to carry on its regular operations; furthermore, the linkage of the exploited production level with actual production level and the market share is essential to determine the utilization level of the natural and manufactured capital.

The incorporation of the upper features within the accounting system expanded the scope of the traditional accounting system to end up with what so called the environmental accounting system which can be defined as" the field that identifies resource use, measures and communicates costs of a company's or national economic impact on the environment. Costs include costs to clean up or remediate contaminated sites, environmental fines, penalties and taxes, purchase of pollution prevention technologies and waste management costs" (From Wikipedia, the free encyclopedia, 2014, Online). the researcher's in the field of environment perceive the necessity of developing and shaping the accountants skills by subjecting them to a training courses to enriches their analytical skills to provide us with an estimates for the environmental issues, On the other hand The interaction of professional and academic knowledge is a must to draft an appropriate environmental standards that meets the new emergent issues (Hooks, 1994).

In an attempt to elicit accountants perceptions regarding corporate social and environmental accounting and reporting practices in a developing country such as Bangladesh, (Islam \& Dellaportas, 2011, p. 64-664) concluded that the accountants have a positive attitudes toward corporate social and environmental accounting, nevertheless the progress is limited, with the absence of The Institute of Chartered Accountants of Bangladesh (ICAB) in making any noticeable effort to develop such practices. Even though, in general the field of accountancy corresponded to the ideas brought by the sustainable development to preserve the environment, which in turn incentivized the researchers to address the environmental and developmental impact on the various field of accounting, in a manner that supports the sustainable development. To reap the required results from the said strategy, three aspects of the accounting discipline should be addressed in a way to contain the environmental issues, (1) Financial accounting (2) Management accounting (Azar et al., 1996). 


\subsection{Environmental Financial Accounting}

The traditional financial statements disclosure is no longer sufficient to meet the stakeholder's requirements arising from the modern business world, as the increased demand for a better quality of life, turned the governing bodies of the accountancy profession into a new strategy that aims to prepare a more informative financial statement's that includes information about the environmental issues to uphold a better living condition. Accordingly, the success of organizations is no longer being measured by the amount of profit generated, instead disclosing the eco efficiency of the company plays a genuine role while evaluating the company's success, since such disclosures meets the global interest in environment simultaneously extends the accountability of organizations beyond the traditional role of providing information to the stakeholder, therefore an international accounting standard should be developed to govern the said disclosures (Mathews, 1997, p. 483).

Stakeholders of an enterprises currently requires an improved level of disclosure about the environmental transactions affecting the entity's financial position and result, due to the fact that such information will help to reduce their credit risk; help them to judge the entity's opportunities and its exposure to risks; and by surrendering to the fact that the current decisions affects the future success of an entity's it can be said that such information will help to compare the future progress between company's (UNCTAD, 1997, p. 13); to approach to this end; an environmental accounts (EA) is required to act as a supporting cornerstones to the financial data portrayed within the financial statements to aid the users to construct a more informative and less risky decisions. The advent of the EA to accounting profession was in 1970 by Norway; thereafter they were adopted by other countries on a gradual bases; and due to increasing interest on the international level to what so called sustainable development; those accounts paved their way to the various industries since their presence provide they users with indicators about the firms performance and future continuity due to the fact that they provide a standardized way to arrange the environmental information borne by the firms interaction with its surrounding's (Lange, 2003, p. 1). To work in conformity with the changes arising from environment, the accountancy profession evolved in a way to contain the environmental costs and revenues, assets and liabilities and as such, should be reported in an enterprise's financial statements(Schaltegger et al., 2008, p. 255). In an attempt to analyses the relationship between environmental protection and mid-term financial performance, (De Burgos-Jiménez et al., 2013, pp. 981-1081) Indicated that there are a positive effect of environmental protection on mid-term financial performance. furthermore, one of the previous studies indicated that the majority of the annual report users believe that the environmental information are material to their decisions; therefore, they seek the disclosure of this information in corporate annual reports (Deegan, Rankin, 1997, p. 562-583).

Based on the previously narrative format, it can be said that there is much to be done by the governing and authoritative bodies of the accounting profession in an attempt to identify a bases to which the natural resources can be recorded, measured, reported by an entity, a breach to this ending can be briefed in establishing a technique by which we can determine the type, quantity, and the relevant unit of measurement for the utilized resources by each industry; and by determining the optimum production level (comparing the actual production with the market share) we can determine the optimum utilization level of the natural resource required by an entity that denotes the mixture of the natural resources used within the production process, and with the presence of predetermined quantity and unit of measurement for each type of the natural resource consumed, the latter can be recorded and measured thus reported within the financial statement, accordingly when upgrading those accounts to national level the total utilization of the natural resources can be computed.

The upper said stream can ensure the efficiency and affectivity of allocating the resources among the industrial sectors, which can be governed by drafting a policy such as the production permits that can be sold to entity's based on the units produced, as such permits denotes the level of contribution of the entity's to the environmental damage, with such strategy in mind the management will tend to rationalize the consumption of the natural resources to the level where it will meet its market share, otherwise they will be paying money without having the chance to recollect it back, and with the ability of trading such permits among the various sectors of the industry a more rival goods and services can be produced with the least utilization level of the natural resources, thus approaching to the well-being required. on the other hand a more disaggregated guidance on how to account for the components involved in the production process (assets, intangible assets, liabilities, costs incurred) should highlight the way to account for the environmental transactions affecting the entity's sustainability, and as such disclosing them within the financial statements of an entity to help enhancing the process of constructing a more rational decisions by reducing the uncertainty level. (Negash, 2012, pp. 577-601) indicated that the credibility of published sustainability reports is unclear, and the size and adequacy of the contributions of the companies towards sharing the costs of decommissioning, rehabilitation and restoration of the environment are not disclosed. 


\subsection{Environmental Management Accounting}

Enterprises now a days are expected or required to account for environmental costs and liabilities, furthermore, they are required to disclose information about their environmental policies, environmental objectives, and programs undertaken along with the associated incurred expenditures (UNCTAD, 1997, pp. 4-6). the interconnectedness of the sustainable development components; turned the managements to a new strategy that aims to include the environmental dimensions in terms of costs and benefits while drafting the economical policies and constructing the relevant decision, such direction is aligned with the principle "the polluter pays", which aims to include the environmental costs while calculating the cost of product (Hassan, 1999). The adoption of such trend (the polluter pays) carries the companies to bear an additional costs arising from the firms noncompliance to the promulgated environmental legislations; hence increasing the production costs, with this stream in mind; companies will tend to reduce the production of harmful products to the environment, thus dumping the markets with a rival products (reducing the amount of resources utilized) that fulfills the desires and needs of the consumer; accordingly supporting the life standards required (Freedman, 1992). Gray indicated that all the accounting research's that addresses a selection of environmental issues should be accompanied with a specific concern for the environment geared to improve the living condition in the world, or at least reduce the rate of damage the world is suffering from(Gray, 2000, pp. 4-11).

The incurred environmental costs arises from the firms interaction with its internal and external environment; and as such they were divided to two main categories (Leontina, Online, p. 126):

A) Internal Environmental Costs: Those costs are borne by the firm such as the remediation and restoration costs, waste management costs, or any other costs driven by the firms compliance to the environmental legislations, the internal environmental cost are subdivided into:

- Direct Costs; that can be traced to a particular product, pollution program, or any other costs borne by the preventive techniques installation to reduce the environmental damage.

- Indirect Costs; that can be allocated to cost centers (Department, Product, Activities); an examples of such costs are the environmental training, R\&D costs.

- Contingent Costs; They comprise of the costs that might occur in the future; simultaneously their occurrence might impact the firms operations (e.g. unforeseen liabilities or remediation costs).

B) External Environmental Costs: Those costs are passed on to the society such as the environmental and health costs; in other words they represent the costs of the environmental damage external to the firm; those costs can be estimated using an economical methods to determine the maximum amount the people of the society are willing to pay to avoid the damage (Gale \& Stokoe, 2001, p. 122).

Typically, the internal environmental costs are more significant to the firm's management than the external environmental cost; unless the occurrence of the latter signals a possibility to recognize a future liability to the firm. Table 1 illustrate the internal and external costs of a firm (Op.cite, p. 124).

Table 1. Environmental costs

\begin{tabular}{|c|c|}
\hline \multicolumn{2}{|c|}{ External Environmental Costs } \\
\hline \multicolumn{2}{|l|}{ Examples: } \\
\hline \multicolumn{2}{|l|}{ - Depletion of natural resources } \\
\hline \multicolumn{2}{|l|}{ - Noise and aesthetic impacts } \\
\hline \multicolumn{2}{|l|}{ - Residual air and water emissions } \\
\hline \multicolumn{2}{|l|}{ - Long-term waste disposal } \\
\hline \multicolumn{2}{|l|}{ - Uncompensated health effects } \\
\hline \multicolumn{2}{|l|}{ - Change in local quality of life } \\
\hline \multicolumn{2}{|c|}{ Internal Environmental Costs } \\
\hline Direct or Indirect Environmental Costs & Contingent or Intangible Environmental Costs \\
\hline Examples: & Examples: \\
\hline - Waste management & - Uncertain future remediation or compensation costs \\
\hline - Remediation costs or obligations & - Risk posed by future regulatory changes \\
\hline - Compliance costs & - Product quality \\
\hline - Permit fees & - Employee health and satisfaction \\
\hline - Environmental training & - Environmental knowledge assets \\
\hline
\end{tabular}




\begin{tabular}{ll}
\hline - Environmentally driven R\&D & $\bullet$ Sustainability of raw material inputs \\
- Environmentally related maintenance & $\bullet$ Risk of impaired assets \\
- Legal costs and fines & $\bullet$ Public/customer perception \\
- Environmental assurance bonds & \\
- Environmental certification/labeling & \\
- Natural resource inputs & \\
- Record keeping and reporting &
\end{tabular}

The absences of the environmental costs while calculating the costs of product or services; can be perceived as if the enterprise is operating independently from its surroundings; which is totally unrealistic, with this assumption in mind; it can be said that the ecological services were drained for a long period of time without any attempt to account for the amount of utilization; which in turn falsified the cost of services and goods introduced to the markets. The environmental costs are those costs arising from the deterioration of actual or potential ecological services due to the economic activities; therefore the containment of such costs is essential to provide a more meaningful data to the decision makers to level the utilization of the ecological services with the growing needs of the society; thus securing the upcoming generation with the stock needed to achieve their well-being (Hassan, 1999). One of the studies stressed that the companies administrations needs to analyze the environmental costs; and place them on the top of the list while calculating the cost of product or service, further; they indicated that the external costs should be converted into internal costs so as to trace them to the relevant product or service cost, which makes it crucial to intervene in the adoption of policies and programs that protect the environment (Zachry et al., 1998).

The containment of environmental costs requires a relevant tool to draft the appropriate accounting practices to account for the said costs, the environmental management can be viewed as the tool through which the enterprise can enhance its economic performance; thus narrowing the gap between the entity and its surrounding's, the achievement of such goal can be approached by including the environmental cost in the management accounting system to enhance the quality of information needed to steer the internal entity towards achieving a better performance by adopting a more informative decisions that takes into consideration the interaction of the entity with its surrounding's, thus preserving the environment and support the sustainable development (IFAC, 2005). Environmental legislation, changing consumer behavior and organizational responsibility are among of the factors that influenced the need for environmental information that led to the establishment of a comprehensive framework for environmental management accounting, in an attempt to rationalize the decision making process, as some previous studies revealed that the associated environmental costs are often not included within the traditional management accounting (UN, 2001, p. 13). whilst others confirmed that the traditional methods of management accounting lacks the efficiency needed to provide the management with the relevant information about the environmental costs to support their managerial decisions, which in turn burst forth a tremendous challenge to develop an information system that allows the integration between the economic and the environmental management accounting aspects (Baker, 1996).

The Environmental management accounting can be defined as "the generation, analysis and use of financial and non-financial information in order to improve corporate environmental and economic performance" (Bennet \& James, 1997, p. 36).

Accordingly, it can be said that environmental management accounting refers to the field of accounting that successfully offers information to the managers, investors and other internal and external users regarding the firm's impact on the environment, Environmental management accounting system can be used by every business to determine whether the environmental goals are met, and if this is not the case, what changes need to occur in order to get back on the environmental protection plan.

\section{Research Methodology}

\subsection{Importance of the Study and Objectives}

The study problem can be concluded with the lack of the annual financial statements to provide information about the environmental issues to enhance the decision making process, which in turn will help to allocate the utilized resources more efficiently and effectively, Therefore, the accountants should be enriched with the potential benefits of developing and implementing the sustainable accounting, to support the sustainable development of the entity. Accordingly this study aims to answer the following questions:

Is there a statistical correlation between the environmental financial accounting and the uphold of sustainable 
development?

Is there a statistical correlation between the environmental management accounting and the uphold of sustainable development?

\subsection{The Study Framework}

The variables of the study can be diagramed as follows

\begin{tabular}{|c|c|c|}
\hline $\begin{array}{l}\text { Independent Variables: } \\
\text { Sustainable Accounting }\end{array}$ & & Dependent Variable: \\
\hline $\begin{array}{l}\text { 1) Environmental Financial } \\
\text { Accounting. }\end{array}$ & & \multirow{2}{*}{$\begin{array}{l}\text { Uphold of the Sustainable } \\
\text { Development }\end{array}$} \\
\hline \multirow[t]{3}{*}{$\begin{array}{l}\text { 2) Environmental Management } \\
\text { Accounting. }\end{array}$} & 4 & \\
\hline & Demographic Variables & \\
\hline & $\begin{array}{l}\text { Personal Characteristics of Respondents: } \\
\text { (Experience, Position, Specialization, Academic Qualification). }\end{array}$ & \\
\hline
\end{tabular}

Figure 1. Study variables

Note. *Designed by the researchers based on previous studies.

\subsection{Hypotheses of the Study}

This study aims to validate the following main hypothesis:

There is a positive statistical significant correlation at $(\alpha=0.05)$ between the sustainable accounting and the uphold of sustainable development at the Jordanian industrial sector.

The following sub hypotheses branch out from the upper said one

First sub hypothesis:

"There is a positive statistical significant correlation at $(\alpha=0.05)$ between the environmental financial accounting and the uphold of sustainable development at the Jordanian industrial sector".

Second sub hypothesis

"There is a positive statistical significant correlation at $(\alpha=0.05)$ between the environmental management accounting and the uphold of sustainable development at the Jordanian industrial sector".

\section{Statistical Analysis}

\subsection{The Study Population and Its Sample}

To research the objective of this study, the researchers identified the Jordanian industrial sector to form the study population, it consists of 70 industrial firms (ASE, 2013, Online), 20 of which were randomized to form the study sample. The sampling unit consisted of (Head of finance, chief accountant, Accountant, internal auditor).

\subsection{Data Collection}

the primary information were obtained by a questionnaire that was developed and distributed among the 150 individuals who formed the sampling unit of the study. out of the whole distributed, 135 were returned, and only 120 were statistically valid, therefore, they were subjected to the statistical analysis using the statistical package of social science (SPSS).

\subsection{Validity and Reliability of the Study Tool}

To test the reliability of the study instruments, alpha coefficient was computed to be $(76 \%)$, which denotes an acceptable rate if compared with the acceptable international one which is somewhere around (60.00\%).

\section{Results \& Discussion}

\subsection{The Sampling Unit Characteristics}

The tabulation below displays the demographic Characteristics of the sampling unit: 
Table 2. Frequencies and the percentages of the demographic characteristics

\begin{tabular}{lll}
\hline Variables & Freq. & Percentages \\
\hline Academic Qualification & & \\
High Diploma & 19 & $15.83 \%$ \\
bachelor degree & 88 & $73.33 \%$ \\
Master Degree & 13 & $10.84 \%$ \\
Total & $\mathbf{1 2 0}$ & $\mathbf{1 0 0 \%}$ \\
\hline Experience & & \\
equals \& less than 5 years & 32 & $26.67 \%$ \\
6-10 years & 38 & $31.67 \%$ \\
11-15 years & 29 & $24 . .16 \%$ \\
15 years and above & 21 & $17.50 \%$ \\
Total & $\mathbf{1 2 0}$ & $\mathbf{1 0 0} \%$ \\
\hline Academic Field & & \\
Accounting & 74 & $61.67 \%$ \\
Business Administration & 15 & $12.50 \%$ \\
Finance & 21 & $17.50 \%$ \\
Other & 10 & $8.33 \%$ \\
Total & $\mathbf{1 2 0}$ & $\mathbf{1 0 0 \%}$ \\
\hline
\end{tabular}

The tabulation above Table 2 shows that the majority of surveyed respondents were holding a bachelor degree as they formed (73.33\%), whereas (15.83\%) were a high diploma holders, and only (10.84\%) were holding a master degree. Meanwhile, the statistical analysis revealed that those whose experience ranged from 6-10 years came at the first place with a percentage of (31.67\%), followed by those whose experience is equal and less than 5 years with a percentage of $(26.67 \%)$. Those whose experience ranged from 11-15 years came at the third place with a percentage of $(24.16 \%)$, to have those whose experience is 15 years and above at the fourth place. furthermore table 2 indicates that the majority of respondents were specialized in accounting as they formed (61.67\%) from the surveyed sample, followed by those whose major was finance as they formed $(17.50 \%)$, as for the respondents specialized in business administration and other specialties they formed $(12.50 \%)(8.33 \%)$ respectively.

\subsection{The Descriptive Statistics}

The below tabulations lists the results of the descriptive statistics (Means, Std. Deviation) for the study variables

Table 3. Means and Std. deviations for sustainable accounting and the uphold of sustainable development

\begin{tabular}{|c|c|c|c|}
\hline No. & Paragraphs & Mean & St. Division \\
\hline 1 & $\begin{array}{l}\text { Sustainable development allows development to meet the needs and requirements of present } \\
\text { generations without compromising the ability of future generations to meet their own needs }\end{array}$ & 4.047 & 0.69677 \\
\hline 2 & $\begin{array}{l}\text { That environmental issues should not be dealt with in a partial manner, instead they should be dealt } \\
\text { with in a comprehensive and integrated manner that aims to achieve economic development without } \\
\text { undermining the environmental resources. }\end{array}$ & 3.452 & 0.69677 \\
\hline 3 & Sustainable development aims to improve the quality and conditions of human life. & 3.857 & 0.56618 \\
\hline 4 & $\begin{array}{l}\text { Sustainable development can be perceived as an equality tool that focus on achieving an } \\
\text { environmental equilibrium that aims to preserve environment }\end{array}$ & 3.619 & 0.76357 \\
\hline 5 & $\begin{array}{l}\text { To support sustainable development, the industrial activities demolishing the environment should be } \\
\text { banned. }\end{array}$ & 3.666 & 0.8165 \\
\hline 6 & $\begin{array}{l}\text { The employed strategy of sustainable development at your premises aims to redirect the used } \\
\text { technology in a way that aims to narrow the associated risks of using such technology. }\end{array}$ & 2.2143 & 0.7168 \\
\hline \multirow[t]{2}{*}{7} & $\begin{array}{l}\text { The applicable procedures of sustainable development at your premises aims to reduce the wasteful } \\
\text { consumption of energy and natural resources by improving the level of efficiency thus upgrading the } \\
\text { human lifestyle }\end{array}$ & 2.1667 & 0.72974 \\
\hline & total & 3.288 & \\
\hline
\end{tabular}

Table 3 indicates that the opinion of the sampling unit were positive in regard to the sustainable development, as 
the analysis revealed that the relevant overall mean equals to (3.288) which in turn exceeds the average of the measurement instruments that corresponds to (3). Furthermore, table 3 indicate that statement No (1)" Sustainable development allows development to meet the needs and requirements of present generations without compromising the ability of future generations to meet their own needs" registered the highest mean (4.047) with a standard deviation of (0.69677), nevertheless, statement No.(7) "The applicable procedures of sustainable development at your premises aims to reduce the wasteful consumption of energy and natural resources by improving the level of efficiency and bring about a radical change in lifestyle" registered the least mean (2.1667) with a standard deviation of (0.72974).

Table 4. Means and Std. deviations for environmental financial accounting contribution to the uphold of sustainable development

\begin{tabular}{|c|c|c|c|}
\hline No. & Paragraphs & Mean & St. Division \\
\hline 1 & $\begin{array}{l}\text { The Work scope of the accountants and the environment officials include procedures and policies } \\
\text { that aims to promote sustainable development initiatives within companies }\end{array}$ & 3.788 & 0.8306 \\
\hline 2 & $\begin{array}{l}\text { The company recognize the environmental liability in the financial statements if the amount of the } \\
\text { loss is probable and possible to evaluate accurately }\end{array}$ & 2.53 & 0.8207 \\
\hline 3 & $\begin{array}{l}\text { The company disclose environmental and social information in its financial statements in addition } \\
\text { to the operational profit. }\end{array}$ & 2.43 & 0.7005 \\
\hline 4 & $\begin{array}{l}\text { The environmental information relevant to your company are disclosed in a descriptive manner in } \\
\text { the financial statements }\end{array}$ & 2.882 & 0.5388 \\
\hline 5 & $\begin{array}{l}\text { The environmental costs and the extent to which your company contribute in addressing pollution } \\
\text { and ways to get rid of the production waste are disclosed to third parties in the annual financial } \\
\text { statements. }\end{array}$ & 2.785 & 0.6967 \\
\hline Total & & 2.8468 & 0.717 \\
\hline
\end{tabular}

Table 4 indicates that the opinion of the sampling unit were positive in regard to the environmental financial accounting contribution to the preservation of the environment and support sustainable development, as the analysis revealed that the relevant overall mean equals to (2.8468) which in turn exceeds the average of the measurement instruments that corresponds to (3). Furthermore, table(3) indicate that statement No (1)" The Work scope of the accountants and the environment officials include procedures and policies that aims to promote sustainable development initiatives within companies." registered the highest mean (3.788) with a standard deviation of (0.8306), nevertheless, statement No.(2) " The company recognize the environmental liability in the financial statements if the amount of the loss is probable and possible to evaluate accurately " registered the least mean (2.43) with a standard deviation of (0.7005).

Table 5. Means and Std. deviations for the environmental management accounting contribution to the uphold of the sustainable development

\begin{tabular}{|c|c|c|c|}
\hline No & Paragraphs & Mean & St. Division \\
\hline 1 & The Economical performance of the entity is considered in the decision making process. & 3.804 & 0.77 \\
\hline 2 & The environmental issues are considered when preparing the capital budgets. & 2.75 & 0.87 \\
\hline 3 & $\begin{array}{l}\text { The company adopt a strategic approach for Management Accounting that takes the economical } \\
\text { and social aspects into consideration }\end{array}$ & 2.9 & 0.98 \\
\hline 4 & $\begin{array}{l}\text { The company is eager to gain a social acceptance through the implementation of managerial polices } \\
\text { that aims to enhance its social image. }\end{array}$ & 3.7678 & 0.76 \\
\hline 5 & The environmental estimations are included in the product cost. & 2.6 & 0.81 \\
\hline 6 & $\begin{array}{l}\text { the company is interested in specifying the type of environmental costs driven by its tendency to } \\
\text { avoid any governmental penalties }\end{array}$ & 3.554 & 0.887 \\
\hline Total & & 3.195 & 0.543 \\
\hline
\end{tabular}

Table 5 indicates that the opinion of the sampling unit were positive in regard to the environmental management accounting contribution to the preservation of the environment and support sustainable development, as the analysis revealed that the relevant overall mean equals to (3.694) which in turn exceeds the average of the measurement instruments that corresponds to (3). Furthermore, table 5 indicate that statement No (1)" The use of 
accounting for sustainable development within the context of the business, and identify appropriate shareholders and ultimately determine the rate of return on investment in sustainable development" registered the highest mean (3.804) with a standard deviation of (0.77), nevertheless, statement No.(2) "The company is eager to gain a social acceptance through the implementation of managerial polices that aims to enhance its social image, such as preventing child employment, ensure the rights of individuals" registered the least mean (3.76) with a standard deviation of (0.76).

\subsection{Validating the Study Hypotheses}

\subsubsection{Main Hypothesis}

It states: There is a positive statistical significant correlation at $(\alpha=0.05)$ between the sustainable accounting and the uphold of sustainable development at the Jordanian Industrial sector. To validate this hypothesis, one sample T. Test for bilateral comparisons at significant of $(\alpha=0.05)$ was employed. Table (6) displays the relevant results:

Table 6. One sample T.test for the main hypothesis

\begin{tabular}{|c|c|c|c|c|}
\hline Statement & Calculated “T” & Mean & Sig. "T" & Decision \\
\hline $\begin{array}{l}\text { environmental accounting and the support of sustainable } \\
\text { development and the preservation of the environment }\end{array}$ & 15.84 & 3.02 & 0.000 & accept hypothesis \\
\hline
\end{tabular}

As indicated in table 6, the calculated "T" equals to (15.84), whereas, and by comparing the results obtained while validating the hypothesis, it is evident that the calculated " $\mathrm{T}$ " is greater than the tabulated " $\mathrm{T}$ ", accordingly we accept the hypothesis stated as" There is a positive statistical significant correlation at $(\alpha=0.05)$ between the sustainable accounting and the uphold of sustainable development at the Jordanian Industrial sector". The result in which we were driven to is confirmed by the amount of Sig."T" that equaled to Zero.

\subsubsection{First Hypothesis}

It states: There is a positive statistical significant correlation at $(\alpha=0.05)$ between the environmental financial accounting and the uphold of sustainable development at the Jordanian Industrial Sector". To validate this hypothesis, one sample T.Test for bilateral comparisons at significant of ( $\alpha=0.05)$ was employed. Table (5) displays the relevant results:

Table 7. One sample T.test for the first hypothesis

\begin{tabular}{|c|c|c|c|c|}
\hline Statement & Calculated “T" & Mean & Sig. "T" & Decision \\
\hline $\begin{array}{l}\text { environmental financial accounting and the support of } \\
\text { sustainable development and the preservation of the } \\
\text { environment }\end{array}$ & 10.544 & 2.8468 & 0.00 & Refuse hypothesis \\
\hline
\end{tabular}

As indicated in table 7, the calculated " $\mathrm{T}$ " equals to (10.544), and by comparing the results obtained while validating the hypothesis, it is evident that the calculated " $T$ " is greater than the tabulated " $T$ ", accordingly we Refuse the hypothesis stated as" There is a positive statistically significant correlation at $(\alpha=0.05)$ between the environmental financial accounting and the uphold of sustainable development at the Jordanian industrial sector". The result in which we were driven to is confirmed by the amount of Sig."T" as it equaled to Zero.

\subsubsection{Second Hypothesis}

It states: There is a positive statistical significant correlation at $(\alpha=0.05)$ between the environmental management accounting and the uphold of sustainable development at the Jordanian industrial sector. To validate this hypothesis, one sample T. Test for bilateral comparisons at significant of $(\alpha=0.05)$ was employed. Table (6) displays the relevant results:

Table 8. One sample T.test for the second hypothesis

\begin{tabular}{lcccc}
\hline Statement & Calculated “T” & Mean & Sig. “T” & Decision \\
\hline $\begin{array}{l}\text { environmental management accounting and the support of } \\
\text { sustainable development and the preservation of the } \\
\text { environment }\end{array}$ & 27.421 & 3.195 & 0.000 & accept hypothesis \\
\hline
\end{tabular}


As indicated in Table 8, the calculated " $\mathrm{T}$ " equals to (27.421), whereas, and by comparing the results obtained while validating the hypothesis, it is evident that the calculated " $\mathrm{T}$ " is greater than the tabulated " $\mathrm{T}$ ", accordingly we accept the hypothesis stated as" There is a positive statistical significant correlation at $(\alpha=0.05)$ between the environmental management accounting and the uphold of sustainable development at the Jordanian industrial sector". The result in which we were driven to is confirmed by the amount of Sig."T" as it equaled to Zero.

\section{Conclusions}

Based on the study results, several conclusions were drafted, among of which are:

1) There is a positive statistical significant correlation between the sustainable accounting and the uphold of sustainable development at the Jordanian Industrial sector. nevertheless, a disaggregated analysis revealed that there is a consensus among the respondents in regard to the applicability of sustainable development since it allows development to meet needs and desires of the present and future generations, such awareness was exemplified by the prevailing belief that the impact of the Jordanian industrial activities will pass on to the society in the form of depletion of natural resources, waste of disposals, water and air pollution which could lead to an uncompensated health effect, accordingly, from the Jordanian industrial perspective; including such aspects as one of the parameters to construct a business decision is essential to the Jordanian human well being, due to the fact that it will help the managerial level to determine the industrial demolishing activities to the environment, thus triggering a new course of action to enhance or replace or eliminate them to bring a balance into the equation of depleting the ecosystem services and the subsequent effects that will pass beyond the firms boundaries. nevertheless, there are a consensus among the respondents regarding the sustainable development strategies and the related procedures in force, as the study analysis revealed that it is in its early stages if compared with other markets, which drive us to conclude that the relevant legislations are not enough to empower the environmental preservations.

2) There is a negative statistically significant correlation between the environmental financial accounting and the uphold of sustainable development at the Jordanian industrial sector, the study analysis indicated that there are a poor amount of environmental information disclosed in the financial statements; even though the policies and procedures in which the environmental officials and accountants are empowered with is taking a growing trend to promote for the sustainable development, and that is cited by the tendency to disclose environmental information in a descriptive manner in financial statements; in addition to the firms contribution in addressing the waste and pollution. on the other hand there is much to be done to start recognizing the environmental costs as a liabilities to the firm.

3) There is a positive statistical significant correlation at $(\alpha=0.05)$ between the environmental management accounting and the uphold of sustainable development at the Jordanian industrial sector. The study analysis revealed that the Jordanian Industrial sector is surrounding the environmental aspects with a moderate interest if compared with the social and economical aspects, as it was noticeable that companies are focusing on the economical performance simultaneously seeking to enhance their social image by following a certain policies such as preventing child employment, ensuring the individual rights. on the other hand it was evident that there is a deficiency in including the environmental estimation within the decision making process, for instance the capital budgeting and the product cost are not shaped up with the environmental estimation which denotes that there is no voluntarily response towards the environmental issues by the firms, nevertheless the study analysis indicates that the environmental response by the firms are limited to the legislations enacted by the governmental bodies to avoid any foreseeable penalties.

\section{Acknowledgement}

The researchers extends their warmest thanks and gratitude to the Applied Sciences Private University (Amman / Jordan) on its financial support to accomplish this article (DRGS2013-2014-46).

Published With the Support of Applied Science Private University.

\section{References}

Albu, N., Nicolae, C., Madalina, M., \& Iuliana, M. (2011). The implications of corporate social responsibility on the Accounting profession: The case of Romania. Amfiteatru Economic, 29, 221-234.

Al-Sheikh, M. S. (2002). The Economic and Financial Effects of Environmental Pollution and Methods of Protection (1st ed.). Alexandria: AL-Fanneiah Library and Press.

Azar, C., Holmberg, J., \& lindgren, K. (1996). Methodological and Ideological options socio-ecological indicators for sustainability. Ecological Economics, $18, \quad$ 89-112. 
http://dx.doi.org/10.1016/0921-8009(96)00028-6

Baker, D. (1996). Environmental Accounting s Conflicts and Dilemmas. Management Accounting, 74(9).

Bennet, M., \& James, P. (1997). Environmental-related management accounting: current practice and future trends. Greener Management International, 17, 32-51.

De Burgos-Jiménez, J., Vázquez-Brust, D., Plaza-Úbeda, A. J., \& Dijkshoorn, J. (2013). Environmental protection and financial performance: an empirical analysis in Wales. International Journal of Operations \& Production Management, 33(8), 981-1018. http://dx.doi.org/10.1108/IJOPM-11-2010-0374

Deegan, C., \& Rankin, M. (1997). The materiality of environmental information to users of annual reports. Accounting, Auditing \& Accountability Journal, $10(4), \quad 562-583$. http://dx.doi.org/10.1108/09513579710367485

Environmental Accounting. (2014). Retrieved from http://en.wikipedia.org/wiki/Environmental_accounting

Feher, P. (2006). Proceedings of the 7th European Conference on Knowledge Management. Academic Conferences Limited, United Kingdom.

$\begin{array}{lllll}\text { Free } & \text { Encyclopedia, } & \text { Sustainable } & \text { Development. } & \text { (2014). }\end{array}$ http://en.wikipedia.org/wiki/Sustainable_development

Gale, J., Robert, P., \& Stokoe, K. P. (2001). Environmental Cost Accounting and Business Strategy. In C. Madu (Ed.), Handbook of Environmentally Conscious Manufacturing (p. 122). Kluwer Academic Publishers. http://dx.doi.org/10.1007/978-1-4615-1727-6_6

Gray, R. B., \& Walters, D. (2000). Accounting and Enviroment: Green Accounting. New York: Markus wiene Publishing inc.

Hassan, A. F. (1999). Accounting Natural and Biological Resources. Cairo University.

Hooks, J. (1994). Providing for Aftercare: problems postponed. Chartered Accountants Journal of New Zealand, 73(10).

International Federation of Accountants (IFAC). (2005). Environmental Management Accounting.

Jeliazkov, D. (2009). Accounting can and should be involved in environmental protection. Financial Audit Review, 12, 50-55.

Kee, P., \& De Haan, M. (2009). Accounting for Sustainable Development. Division of Macro-economic Statistics and Dissemination Development and support department.

Koellner, T. (2011). Ecosystem Services and Global Trade of Natural resources. Routledge: Exploration in Environmental Economics, USA.

Lange, G. M. (2003). The World Bank Environment Department, Environmental Economical Series: Policy Applications of Environmental Accounting. Paper No. 88, New York, USA. Retrieved from http://siteresources.worldbank.org/INTEEI/214574-1115814938538/20486189/PolicyApplicationsofEnviro nmentalAccounting2003.pdf

Leontina, B. (2014). Environmental Cost Accounting. University of Iasi. Retrieved from http://steconomiceuoradea.ro/anale/volume/2007/v2-finances-accounting-and-banks/26.pdf

Mathews, M. R. (1997). Accounting, Auditing \& Accountability Journal, 10(4), 481-531. http://dx.doi.org/10.1108/EUM0000000004417

Moisescu, F., \& Mihai, O. (2006). Environmental Financial Accounting. The Annals of "Dunarea De Jos" University of Galati. Economics and Applied Informatics, Year XII, ISSN 1584-0409. Retrieved from http://www.ann.ugal.ro/eco/ Doc\%202006/16.\%20OK\%20Moisescu.pdf

Negash, M. (2012). IFRS and environmental accounting. Management Research Review, 35(7), 577-601. http://dx.doi.org/10.1108/01409171211238811

Nicolae, T., Ionela, C. S., \& Ana, M. J. (2010). Environmental accounting - a tool used by the entity for determining environmental costs. Annales Universitatis Apulensis Series Oeconomica, 12(1), 207-217.

Quick, B. (2014). Ways to Increase Public Awareness About Environmental Problems. Retrieved from http://classroom.synonym.com/ways-increase-public-awareness-environmental-problems-2590.html

Qureshi, Z. N., Kulshrestha, D., \& Tiwari, B. S. (2012). Environmental Accounting and Reporting: An Essential Component of Business Strategy. Asian Journal of Research in Banking and Finance, 2(4), 85-95. 
Schaltegger, S., Burritt, L. R., Bennett, M., \& Jasch, C. (2008). Environmental Management Accounting For Cleaner Production. Springer Science \& Business, 255.

Strange, T., \& Bayley, A. (2008). Sustainable Development: Linking Economy, Society, Environment (pp. 24-25). Organization for Economic Co-operation and Development (OECD).

United Nation Division for Sustainable Development. (2001). Paperead: Promoting environmental management accounting through government policies and programmers (pp. 1-12). Department of Economic and Social Affairs, New York.

United Nations Commission on Environment and Development. (1992). New York: UNCED.

United Nations Conference on Trade and Development. (1997). Environmental Financial Accounting and Reporting at the Corporate Level. Retrieved from http://unctad.org/en/docs/isa15d2.pdf

United Nations Environment Program. (2014). Planning and Management of Lakes and Reservoirs: An Integrated Approach to Eutrophication. Ch.4: Public Awareness and environmental Education. Retrieved from http://www.unep.or.jp/Ietc/Publications/techpublications/TechPub-11/4-2.asp

World Commission on Environment and Development. (1987). Our common future, Oxford University.

Zachry, B. R., Gaharan, C. G., \& Chaisson, M. A. (1998). A Critical Analysis of Environmental Costing. American Business Review, 16(10).

\section{Copyrights}

Copyright for this article is retained by the author(s), with first publication rights granted to the journal.

This is an open-access article distributed under the terms and conditions of the Creative Commons Attribution license (http://creativecommons.org/licenses/by/3.0/). 